\title{
SOME ISSUES OF THE DEVELOPMENT OF PUBLIC HEALTH IN UKRAINE
}

\author{
Hushchuk I.V. \\ ДЕЯКІ ПИТАННЯ РОЭБУДОВИ СИСТЕМИ \\ ГРОМАДСЬКОГО ЗДОРОВ’Я УКРАӤНИ
}

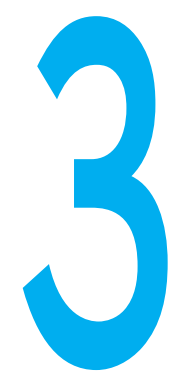

ГУЩук І.В.

Національний університет

«Острозька академія», м. Острог

УДК 614

Ключові слова: здоров'я, людина, захворюваність, профілактика, система громадського здоров'я. доров'я населення $€$ однією з найбільших цінностей суспільства і основним критерієм якості життя населення. На міжнародному рівні це позначено в Європейському стратегічному плані «Здоров'я-2020: основи Європейської політики на підтримку дій держави і суспільства в інтересах здоров'я і благополуччя». Зазначені положення також декларує Конституція України, у статті 3 якої визначено: «Людина, її життя і здоров'я, честь і гідність, недоторканість і безпека визнаються в Україні найвищою соціальною цінністю».

Водночас реальні демографічні показники країни з початку 1990-х років мають тенденції до погіршення.

За даними Європейського регіонального бюро Всесвітньої організації охорони здоров'я (ВООЗ), сучасний стан здоров'я населення України характеризується вкрай високими показниками захворюва- ності та смертності, низьким рівнем тривалості життя, відсутністю можливості отримувати належну медичну допомогу.

Так, середня тривалість життя в Україні на 5 років нижча, ніж в Європейському регіоні і на 9 років нижча, ніж у країнах Європейського Союзу. За даними Державного комітету статистики України, лише 15\% загальної кількості наших громадян є старшими за 65 років.

Порівняно 3 країнами $\Theta_{\text {в- }}$ ропи смертність населення в Україні практично вдвічі вища (у 2014 році - 14,7 випадків на 1000 населення проти 6,7 у країнах-членах Європейського Союзу). При цьому смертність через серцевосудинні захворювання $€$ однією $з$ найвищих у світі та становить $67,3 \%$ у структурі загальної смертності, а смертність через онкологічні захворювання - 13,3\% (дані МОЗ України за 2014 рік). Фактично ці класи
НЕКОТОРЫЕ ВОПРОСЫ РАЗВИТИЯ

ОБЩЕСТВЕННОГО ЗДРАВООХРАНЕНИЯ УКРАИНЫ

Гущук И.В.

Национальный университет "Острожская академия", г. Острог

Целью данной работы является анализ современного состояния развития общественного здравоохранения в Украине.

Материалы и методы исследования.

Материалом исследования послужили статистические отчеты о состоянии здоровья населения Украины, показатели деятельности отечественной системы здравоохранения, концептуальные документы по ее реформированию и нормативные базы документов международных и региональных организаций, публикаций из опыта профилактики инфекционных и неинфекционных заболеваний в других странах с фукционирующей системой общественного здравоохранения. В работе были использованы такие методы: библиографические, исторические, аналитические, сравнительные и метод системного подхода.
Результаты. Центральное место в европейском стратегическом плане «Здоровье-2020: основы европейской политики в поддержку действий государства и общества в интересах здоровья и благополучия" уделяется охране здоровья населения. Современное состояние здоровья населения Украины (по данным Европейского регионального бюро ВОЗ) характеризуется очень высокими показателями заболеваемости и смертности, низкой продолжительности жизни, отсутствием возможности получить надлежащую медицинскую помощь.

Выводы. Ситуация, сложившаяся в сфере общественного здоров'я, на государственном уровне приобретает чрезвычайный характер и несет угрозы национальной безопасности, которая осложняется отсутствием осознанного отношения граждан к необходимости ведения здорового образа жизни. При этом система здравоохранения сосредоточивает свое внимание преимущественно на лечении и почти не уделяет внимания профилактике болезней.

Ключевые слова: здоровье, человек, заболеваемость, профилактика, система общественного здравоохранения.

(с) Гущук I.В. СТАТТЯ, 2016. 
SOME ISSUES OF THE DEVELOPMENT OF PUBLIC HEALTH IN UKRAINE

Hushchuk I.V.

"Ostroh Academy" National University, Ostroh

Objective. Analysis of the current state of the development of public health in Ukraine.

Materials and methods. In research we used the statistical reports on the state of health of the population of Ukraine, indices of the activity of national public health system, conceptual documents on its reformation and regulatory framework of the documents of international and regional organizations, publications on the experience of the prevention of infectious and non-infectious diseases in other countries with the operating system of public health. We used the following methods: bibliographical, historical, analytical, comparative, and systematic ones.

Results. Central place in the European strategic plan "Health-2020: Fundamentals of European
Policy in Support of Actions of the State and Society in the Interests of Health and Well-Being" is given to the population health protection. The current state of health of the Ukrainian population (according to the data of the WHO Regional Office for Europe) is characterized by the very high rates of morbidity and mortality, low life expectancy, lack of the opportunities to receive an appropriate medical care.

Conclusions. The situation in the sphere of public health at the state level assumes an extraordinary character and brings a threat to the national security which is complicated by the lack of conscious attitude of the citizens to the need of the introduction of a healthy lifestyle. With this provision a health care system concentrates its attention on the treatment and doesn't almost give consideration for the prevention of diseases.

Keywords: health, man, incidence, prevention, public health systems. хвороб визначають 80\% ни та соціально-економічні щорічних втрат населення України.

Вдвічі вищим за країни Європейського Союзу $€$ й рівень малюкової смертності, що вважається одним 3 основних показників якості роботи системи охорони здоров'я.

При цьому показник природного приросту населення в Україні залишається від'ємним, а сумарний коефіцієнт народжуваності становить лише 1,5 дитини на одну жінку, тоді як для досягнення рівня простого відтворення населення він має становити 2,1.

Мета роботи полягає в аналізі сучасного стану розбудови системи громадського здоров'я (СГЗ) в Україні.

Матеріали і методи досліджень. Матеріалом досліджень служили статистичні звіти про стан здоров'я населення України, показники діяльності вітчизняної системи охорони здоров'я, концептуальні документи з її реформування та нормативно-правова база, документи міжнародних і регіональних організацій, публікації з досвіду попередження інфекційних та неінфекційних захворювань в інших країнах на засадах системи громадського здоров'я.

У роботі використовувалися бібліографічний, історичний, аналітичний, порівняльний методи та метод системного підходу.

Результати дослідження та їх обговорення. Проблеми здоров'я населення, їх причи- наслідки. Генеральна Асамблея Організації Об'єднаних Націй ще у вересні 2011 року прийняла історичне рішення і політичну декларацію про профілактику та боротьбу з неінфекційними захворюваннями, визначивши пріоритетним напрямом у цій сфері боротьбу $з$ серцево-судинними захворюваннями, діабетом, захворюваннями органів дихання i раком.

Ця декларація є чіткою ознакою того, що світове співтовариство і лідери держав усвідомлюють руйнівну роль неінфекційних хвороб в усьому світі та необхідність рішучих дій щодо її максимально можливого зменшення [1].

Вкотре Програмою діяльності Кабінету Міністрів України, затвердженою Постановою Верховної Ради України від 11.12.2014 p. № 26-VIII та Стратегією сталого розвитку "Україна-2020", затвердженою Указом президента України від 12.01.2015 р. № 5/2015, реформу охорони здоров'я визначено одним з пріоритетних напрямів державної політики.

Актуальність такої реформи $€$ безсумнівною, оскільки ця надзвичайно важлива сфера суспільного життя багато років поспіль потерпає через непослідовну соціально-економічну політику та, на відміну від інших галузей, практично повністю продовжує функціонувати за застарілою, неефективною моделлю управління та фінансування.
Протягом останніх років, незважаючи на високі загальні витрати, система охорони здоров'я не здатна адекватно протистояти зростанню захворюваності, захистити громадян від надмірних витрат на лікування.

На жаль, серед населення країни нині не розвинене усвідомлення громадянами відповідальності за своє здоров'я та необхідності здорового способу життя. Нераціональне харчування, споживання неякісної питної води, масове нехтування заняттями фізичною культурою і спортом, пияцтво, тютюнопаління та інші шкідливі звички для багатьох українців $€$ нормою життя.

При цьому система охорони здоров'я зосереджує свою увагу переважно на лікуванні і майже не приділяє уваги профілактиці хвороб.

I хоча, за даними державної статистики, на систему охорони здоров'я закладено майже 7,4\% обсягу ВВП України, що перевищує показники деяких країн Європейського Союзу, якість лікувальної допомоги залишається на низькому рівні і поступається переважній більшості країн європейського регіону.

Після підписання 2014 року Угоди про асоціацію між Україною та Європейським Союзом, Україна, обравши євроінтеграційний вектор, мала забезпечити поступове наближення до європейських стандартів в охороні здоров'я шляхом здійснення системно- 
го реформування галузі, спрямованого на створення системи, орієнтованої на пацієнта, спроможної забезпечити медичне обслуговування усіх громадян України на рівні розвинутих європейських держав. Орієнтиром реформи було визначено програму Європейського Союзу "Європейська стратегія здоров'я2020".

Однак незважаючи на задекларовану державою важливість здійснення системного та комплексного реформування сфери охорони здоров'я Міністерство охорони здоров'я України реалізує державну політику у цьому напрямі вкрай недостатньо та безсистемно.

До цього практично не зрушилося 3 мертвої точки питання створення єдиного медичного простору, що призводить до неефективного використання і без того вкрай обмежених коштів державного бюджету.

Значні недоліки мають місце в інформаційно-роз'яснювальній та просвітницькій роботі, у ході якої мають доступно та обґрунтовано висвітлюватися зміст заходів щодо реалізації реформи у сфері охорони здоров'я та її очікувані результати.

Світова практика охорони здоров'я протягом XIX-XX століть виробила кілька моделей організації системи медичної допомоги.

При цьому спільний напрямок еволюції національних систем охорони здоров'я пов'язаний 3 пошуком конструктивних рішень у площині практично протилежних тенденцій.

3 одного боку, в усіх країнах спостерігається постійне зростання вартості медичних послуг, викликане об'єктивним ускладненням професійної діяльності, здорожчанням медичної апаратури, медикаментів тощо.

3 іншого боку, уряди більшості країн здійснюють політику, спрямовану на забезпечення соціальної стабільності і задоволення основних життєвих потреб громадян незалежно від їхнього майнового стану [2].

Аналіз шляхів реформування системи охорони здоров'я у

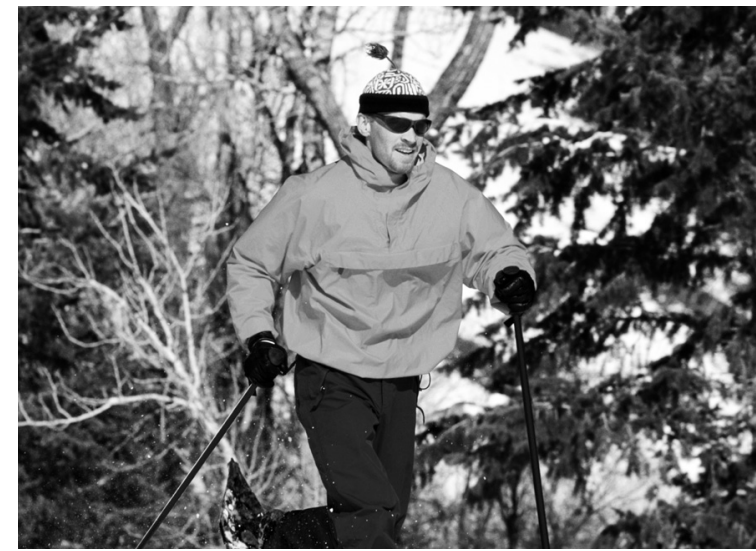

ЗДОРОВ'я НАЦії-

світі свідчить, що можливі варіанти переходу до однієї з відомих моделей або $є$ неприйнятними для України, або не можуть бути реалізованими економічно. Тому для реформування галузі необхідно знайти нове конструктивне рішення, що враховує реалії нашої соціально-економічної ситуації.

При цьому необхідно вирішити триєдине завдання:

$\square$ привести систему охорони здоров'я у відповідність до нових економічних та політичних умов країни;

$\square$ врахувати світові тенденції розвитку охорони здоров'я та передові політики у цій галузі;

$\square$ у перехідний період необхідно зберегти переваги моделі Семашка М.О. перед іншими системами шляхом надання переваги профілактичній медицині.

Як вище вказувалось, Україна, підписавши у першому півріччі 2014 року пакет документів про асоціацію 3 Євросоюзом, взяла на себе низку політичних і соціальноекономічних зобов'язань. Серед них - побудова нової Національної системи охорони здоров'я, в основі якої лежить організація громадського здоров'я, що базується на засадах превентивної (профілактичної) медицини і спрямована на попередження виникнення хвороб, продовження активного життя і зміцнення здоров'я людини як передумови сталого розвитку та економічного зростання [3], основні напрямки яких визначені Всесвітньою організацією охорони здоров'я (Резолюція EUR/RC61/R2 до "Європейського плану дій зі зміцнення потенціалу та послуг охорони громадського здоров'я" [4]:
○ епіднагляд та оцінка стану здоров'я і благополуччя населення;

$\square$ моніторинг та реагування на небезпеки для здоров'я, у т.ч. при надзвичайних ситуаціях у галузі охорони здоров'я;

口 захист здоров'я, включаючи забезпечення безпеки довкілля, праці, харчових продуктів тощо;

口 зміцнення здоров'я, включаючи вплив на соціальні детермінанти і скорочення нерівностей за показниками здоров'я;

口 профілактика хвороб, включаючи раннє виявлення порушень здоров'я;

口 забезпечення стратегічного керівництва в інтересах здоров'я і благополуччя;

$\square$ забезпечення сфери суспільної охорони здоров'я кваліфікованими кадрами достатньої чисельності;

口 забезпечення стійких організаційних структур і фінансування;

口 інформаційно-роз'яснювальна діяльність (адвокація), комунікація та соціальна мобілізація в інтересах здоров'я;

口 сприяння розвитку досліджень у галузі суспільної охорони здоров'я для наукового обґрунтування політики і практики.

Якщо до останнього часу зазначені питання тією чи іншою мірою належали компетенції державної санітарно-епідеміологічної служби (ДСЕС), то нині вони є складовою системи громадського здоров'я і відповідно до цього неважко передбачити доцільність для їх реалізації використовувати не лише рекомендації ВОО3, але й накопичений вітчизняний досвід.

На жаль, у результаті дій урядових установ останніх років система базових засад профілактичної медицини була фактично зруйнована. Це не дає 
змоги адекватно реагувати на шкідливий вплив факторів середовища життєдіяльності людини та її здоров'я, що призводить до погіршення санітарно-епідемічної ситуації на місцевому, регіональному та національному рівнях. Особливу тривогу у фахівців викликає факт збільшення частоти групових інфекційних захворювань серед населення 3 водним та харчовим шляхом передачі.

Стрімка втрата висококваліфікованих та досвідчених фахівців у галузі профілактичної медицини, на підготовку яких держава витратила десятки років, унеможливлює комплексне виконання основних оперативних функцій громадського здоров'я, тоді як вони могли б стати кадровим мобілізаційним ресурсом на перехідний період при розбудові системи громадського здоров'я [5].

\section{Міжгалузеве та міжсекторальне партнерство між владою та громадянським суспільством за принципом іiі “Охорона здоров"я в усіх політиках держави"}

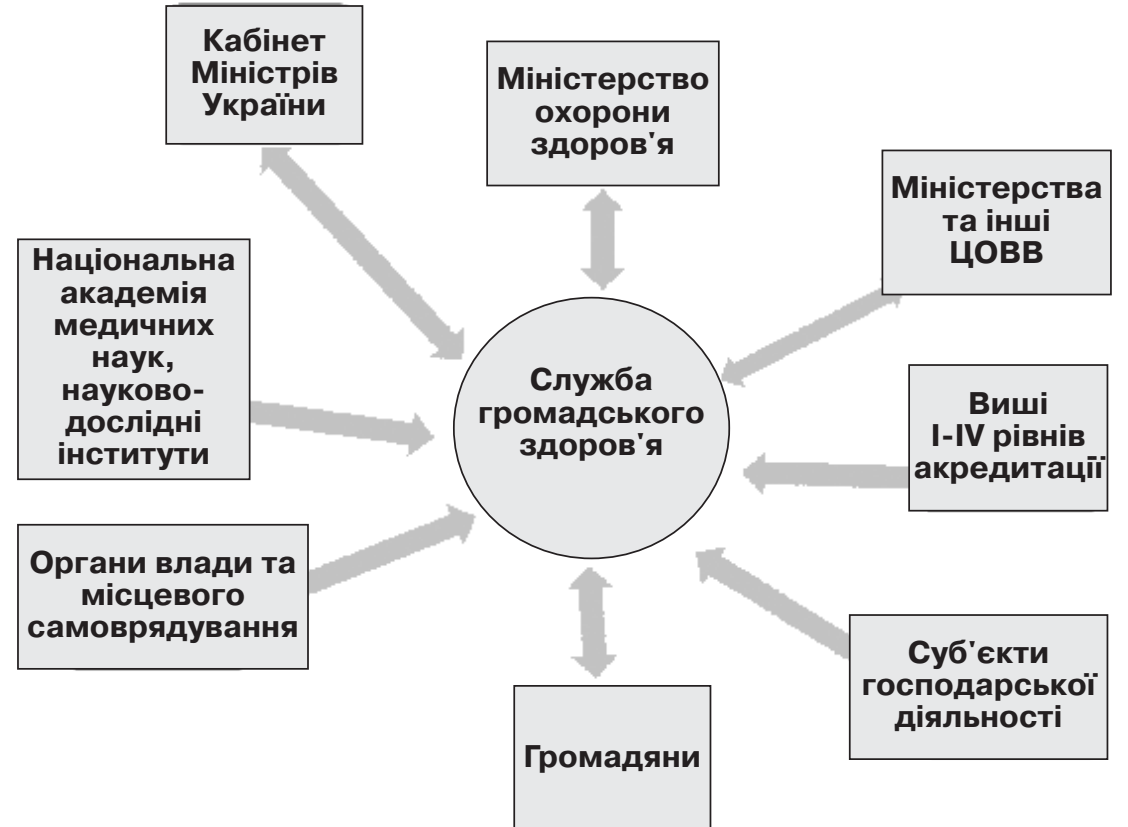

пільних послуг населенню на національному, регіональному та місцевому рівнях, а також здійснювати заходи, що впливають на організацію діяльності інших галузей (міністерств, держкомітетів, держслужб, агенцій та ін.). При цьому необхідно приділяти увагу соціальним, екологічним та економічним детермінантам здоров'я і закріпити законодавчо принцип «Охорона здоров'я в усіх політиках держави» .

Закон про громадське здоров'я має передбачати комплексне реформування складових системи охорони здоров'я, забезпечення надання послуг на рівні розвинених європейських держав, відповідати намірам наближення до законодавчих, нормативних та адміністративних актів держав-членів $\in C$, які визначені програмою «європейська стратегія здоров'я-2020» та іншими стратегічними документами, що формують політику у сфері охорони здоров'я.

3 іншого боку, ефективність реалізації цього питання пов'язана $з$ проведенням адміністративно-територіальної реформи та визначенням ролі і місця громадського здоров'я на усіх рівнях управління (місцевому, регіональному та національному).

Водночас необхідно адаптувати існуючу національну нормативно-правову базу до вирішення нових завдань у сфері охорони громадського здоров'я, а також її систематизації та корекції відповідно до вимог ВООЗ та ЄС тощо.

Причому реалізацію цих складних питань має здійснювати MOЗ та НАМН України у тісній співпраці шляхом міжгалузевого та міжсекторального партнерства між владою та громадянським суспільством за принципом "Охорона здоров'я в усіх політиках держави" (рисунок).

Водночас необхідно вжити заходи з запровадження спеціальності та спеціалізації «громадське здоров'я» та впровадити відповідні навчальні програми базової та післядипломної освіти. Для цього терміново внести зміни до Постанови КМУ від 29.04.2015 р. № 266 «Про затвердження переліку галузей знань і спеціальностей, за 
якими здійснюється підготовка фахівців вищої освіти» щодо додаткового включення до переліку спеціальностей у галузі «Охорона здоров'я» спеціальність «Громадське здоров'я».

Враховуючи практичний досвід, кадрове та матеріально-технічне забезпечення ДСЕС на перехідний період реформування (2016-2020), можливо створити національну інституцію у вигляді Служби громадського здоров'я у складі МОЗ, яка з 2020 року після підготовки та випуску фахівців за спеціальністю «Громадське здоров'я» трансформується у національне Агентство громадського здоров'я (з максимальним обмеженням контрольно-наглядових та значним розширенням моніторингових та експертних функцій).

\section{Висновки}

Проблеми, що існують нині у сфері громадського здоров'я, створюють загрозу національній безпеці держави і потребують негайного вирішення.

Розбудова системи громадського здоров'я в Україні можлива лише через розробку і затвердження відповідної Концепції, Стратегії, Плану дій та Закону і впровадження базового принципу "Охорона здоров'я в усіх політиках держави". Для цього необхідно організувати та провести попередню оцінку наявності сильних та слабких сторін щодо базових задач ГЗ, самооцінку виконання основних 10 оперативних функцій у сфері ГЗ (за методичним інструментарієм ЄРБ ВООЗ).

Необхідно терміново вжити заходи з запровадження спеціальності та спеціалізації «Громадське здоров'я» та впровадження відповідних навчальних програм базової та післядипломної освіти.

ЛІТЕРАТУРА

1. Резолюція «круглого столу»: «Розвиток системи громадського здоров'я в Україні» 22.04.2016 р., м. Київ (Комітет охорони здоров'я Верховної Ради України) [Електронний ресурс]. - Режим доступу: https://drive. google.com/file/d/OB Q9xEu1X ckzbFdOblFhbmNTTGs/view

2. Гущук I.В. До питань розбудови нової моделі націо- нальної системи охорони здоров'я // Мистецтво лікування. - 2016. - № 1-2. - C. 28-30.

3. Проект Національної стратегії побудови нової системи охорони здоров я України на період 20152025 рр. [Електронний ресурс]. - Режим доступу: http://healthsag.org.ua/wpcontent/uploads/2014/11/Proe kt-Strategiyi-reformi OZ.pdf

4. Европейский план действий по укреплению потенциала и услуг общественного здравоохранения / Европейский региональный комитет ВОЗ [Электронный ресурс]. Режим доступа:

http://www.euro.who.int/ data /assets/pdf_file/0008/171773/ RC62wd12rev1-Rus-

updated.pdf

5. Гущук I.В. До питання кадрового забезпечення системи охорони громадського здоров'я // Державне управління людськими ресурсами у сфері охорони здоров'я в Україні: матер. наук.-практ. конф. (Київ, 23.03.2016 р.) / за заг. ред. Ю.В. Ковбасюка В.М. Князевича, Н.О. Васюк. Київ, 2016. - С. 52-54.

\section{REFERENCES}

1. Rezoliutsiia «kruhloho stolu»: «Rozvytok systemy hromadskoho zdorovia v Ukraini» 22.04.2016 (Komitet okhorony zdorovia Verkhovnoi Rady Ukrainy) [Resolution of "Round Table": "Development of the System of Public Health in Ukraine", April 22, 2016 (Committee for Public Health Protection of the Verkhovna Rada of Ukraine)]. Available at : https://drive.google.com/file/ d/OB Q9xEu1XckzbFdOblFhbm NTTGs/view (in Ukrainian).

2. Hushchuk I.V. Mystetstvo likuvannia. $2016 ; 1-2: 28-30$ (in Ukrainian).
3. Proekt Natsionalnoi stratehii pobudovy novoi systemy okhorony zdorovia Ukrainy na period 2015-2025 [Draft of the National Strategy for the Construction of the New System of Public Health Protection in Ukraine for 2015-2025]. Available at : http://healthsag.org.ua/wpcontent/uploads/2014/11/Proe kt-Strategiyi-reformi_OZ.pdf (in Ukrainian).

4. WHO Regional Office for Europe European Action Plan for Strengthening Public Health Capacities and Services.

Available at: http://www.euro.who.int/_data /assets/pdf file/0008/17 $\overline{1773 /}$ RC62wd12rev1-Rus-

updated.pdf

5. Hushchuk I.V. Do pytannia kadrovoho zabezpechennia systemy okhorony hromadskoho zdorovia [On the Issue of Staff Ensuring of the Public Health Protection System]. In : Derzhavne upravlinnia liudskymy resursamy u sferi okhorony zdorovia v Ukraini : materialy konferentsii

[State Management of Human Resources in the Sphere of Public Health Protection in Ukraine :

Proceedings of the Conference]. Kyiv ; 2016 : 52 54 (in Ukrainian).

Надійшло до редакції 14.08.2016

* - "Охорона здоров'я в усіх політиках держави " - загальнонаціональний (загальнодержавний) принцип визнання пріоритетності безпеки у питаннях життя і здоров'я людини, безпечного середовища ї̈ життєдіяльності перед будь-якими іншими інтересами і цілями у сфері господарської діяльності, функціонування суспільства на засадах збалансованого розвитку.

Вживається у розумінні того, що "здоров'я" як поняття включає багато різноманітних значень. Є складним. Це багатогранна, у т.ч. філософська категорія, що містить не тільки медико-біологічні, але й соціальні та економічні аспекти.

За даними ВОO3, до факторів ризику, від яких залежить стан здоров'я населення, належать медичні фактори (якість та своєчасність медичного обслуговування), що впливають тільки на 8-10\%, генетичні - на 1822\%, фактори, що пов'язані зі способом життя - 49-53\%, зі станом довкілля - 17-20\%. Тобто здоров'я людини майже на 70\% залежить від багатьох чинників, на більшість з яких МОЗ не має прямого (безпосереднього) впливу. 